\title{
DISASTER RISK MANAGEMENT AND COMMUNITY RESILIENCE
}

\begin{abstract}
SUMMARY: Natural disasters are present in different parts of the world. They bring many challenges for society and individuals. These challenges require people and communities to be ready and able to efficiently respond in a way that can accelerate the re-establishment of social order and social functioning. An effective community response involves developing strategies to cut the risk of natural disasters that encompass multiple issues: maintaining a built environment, developing warning systems and developing knowledge and capabilities for community response, etc. Since mitigation and warning processes are never fully effective, the development of a resilient society must focus on learning and developing community knowledge, understanding the dangers and developing the ability to respond and adapt.
\end{abstract}

Key words: disaster, risk management, community, resilince, learning

\section{INTRODUCTION}

Numerous studies indicate the importance of learning so communities could be resilient to natural disasters (Petal, 2008). The importance of formal and non-formal, as well as informal learning in this field is emphasized. Our focus on non-formal learning starts with the opportunities that non-formal education opens to the integration of learning about natural disasters/from natural disasters into community processes, especially given the need to personalize education in a way that facilitates its applicability in local contexts where people experience natural hazards.

"Community" can be defined as a group of people connected through their common characteristics or common interests, such as geography, interests, occupation, and culture (Faroog et al.

*Vesna Nikolić, PhD, (vesna.nikolic@znrfak.ni.ac.rs), University of Niš, Faculty of Occupational Safety in Niš, 18000 Niš, Serbia, Mirjana Galjak, PhD, (marta7@ptt.rs), Technical College of Applied Sciences, 38218 Leposavic, Serbia, Josip Taradi, PhD, (josip.taradi@ medjimuirske-vode.hr), Međimurske vode d.o.o., 40000 Čakovec, Hrvatska.
2007). Natural hazard events typically have geographically defined impacts. Location communities are those where residents find and associate with those in the geographic or neighboring location where they live. Paton and Irons (2016) demonstrated how non-formal learning can be used in community learning to cope with the effects of fire disasters and to adapt to a disaster. The need for community adjustment is recognized because of the role that social affiliation plays in how people personalize and localize their risk and develop ways to enact their risk reduction plans (Paton et al. 2017).

\section{NATURAL DISASTERS}

Natural disasters are the consequences of mutual influence of natural events (geophysical and other processes in nature) and human systems (socio-economic, cultural and physical). They have a high and tragic impact on society, they damage the usual ways of life, hinder economic, cultural, and sometimes political conditions of life, slow down the development of the community, and 
require undertaking of extraordinary measures by emergency rescue services during emergency situations.

Natural and other disasters (chemical, biological, nuclear, traffic accidents, mass attacks on populations, etc.), are on the rise on a global scale (WHO, 2009). Natural disasters and incidents can influence greatly the psychophysical health of a population, especially in the most vulnerable groups such as children, pregnant women and the elderly (Palmer et al., 2000). For example, in 2011. in Japan, the earthquake and tsunami in Tohoku caused enormous human suffering. Over 100,000 people were evacuated from their homes, and 19,000 people lost their lives (World Nuclear Association, 2012). According to data provided by EM-DAT, about $50 \%$ of the least developed countries face a high risk of natural disasters. At least a quarter of underdeveloped countries have been hit by major disasters in the last two decades at the rate of two to eight times a year (EM-DAT, 2013). Better-off societies are not per se protected from natural hazards, but they build up to higher standards, invest more in protective infrastructure and can more efficiently provide medical and other relief after a disaster occurs (Kahn, 2005, Anbarci et al. 2005). In the last decades, not only the tendency of increasing the number of natural disasters is evident, but also their destructiveness is increased.

Elemental calamities and other natural disasters show how much a society is vulnerable, or on the other hand, resilient and ready to react appropriately. The consequences of natural disasters are immense, both for society and for the environment. Hence, disaster risk management is crucial in order to reduce risks, limit the consequences, and increase the resilience of a society to disasters. In some situations, risk elimination is hardly possible, so risk assessment can provide significant information to risk managers and other decision makers. Also, putting an emphasis on education in disaster risk management, as well as learning from past natural disasters, leads to disaster risk reduction.

Natural disasters are created by the action of natural forces, and are manifested as the formation of earthquakes, floods, droughts, avalanches, volcanic eruptions, etc. They are characterized by their sudden emergence, although modern technology provides the possibility of predicting some natural threats (floods, hurricanes, droughts, low temperatures, etc.) (Galjak, Nikolić, 2016). Over time, the interpretation of natural disasters has moved from a natural phenomenon which a man does not influence, to human responsibility. According to Steinberg (2013), "calling a disaster a natural act is a distraction. It arises as a result of poor planning and lack of preparation."

According to the Law on Disaster Risk Management and Emergency Management of the Republic of Serbia, "a natural disaster is the occurrence of hydrological, meteorological, geological or biological origin caused by the action of natural forces such as earthquakes, floods, torrents, storms, heavy rains, atmospheric discharges, hail, droughts, mudslides and landslides, snowdrifts and avalanches, extreme air temperatures, accumulation of ice on the watercourse, pandemics, epidemics of contagious diseases, epidemics of livestock contagious diseases and the appearance of pests, and other natural occurrences of larger proportions that could endanger the safety, lives and health of the larger number of people, material and cultural goods or the environment on a larger scale". According to the same source, "a disaster represents an elemental calamity or a technical and technological disaster whose consequences endanger the safety, lives and health of the larger number of people, material and cultural goods or the environment on a larger scale, and whose origin or consequences cannot be prevented or eliminated by regular actions of the competent authorities and services" (Zakon o smanjenju rizika od katastrofa i upravljanju vanrednim situacijama "Službeni glasnik RS" br. 87/2018).

Not every elemental calamity is considered to be a disaster. The concept of natural disaster is manifested by the negative effect of elemental calamity on people and human society. So, when a naturally occurring event leads to negative consequences for people it is called a natural disaster. Any threat - flood, earthquake, or cyclone - which represents an activating event, together with greater vulnerability, leads to a disaster, causing great losses in life and property. For example, an earthquake in an uninhabited desert cannot be regarded as a disaster, regardless of its intensity. 
Depending on the nature of the process of formation natural disasters can be divided into: geophysical (earthquakes, volcanoes, tsunamis, landslides, etc.); meteorological (thunderstorms, tornadoes, hail storms, snowstorms, ice storms, avalanches, etc.); hydrological (floods, torrents); biological (epidemics and insect plagues) and extraterrestrial (meteors) (Edward, 2005, Tobin, Montz, 2007, Mlađan, Cvetković, 2013). Also, natural disasters can be classified according to their place of origin, the source of origin, the speed of their occurrence, etc.

Disasters occur when hazards have a negative impact on the community that is susceptible to them. According to some authors, natural hazards do not always have to turn into disasters. Natural hazards will probably become catastrophic if people who are sensitive to danger are exposed to their influence (Oliver-Smith et al. 2012, Schumacher and Strobl, 2011), i.e. if they are not resistant to total absorption of impacts without damaging lives or property (Schvab et al., 2007; Paul, 2011). Resilience is the ability of a community facing threats to respond to those threats and recover from the consequences of disasters in a timely and effective manner, which also includes the preservation and restoration of basic functions (Zakon o smanjenju rizika od katastrofa i upravljanju vanrednim situacijama "Službeni glasnik RS" br. 87/2018).

Essentially, consequences of natural disasters are equally harmful to human lives, property, infrastructure and natural resources (Shaluf, 2007), which points to the need for a serious approach to the research and study of the risks of natural disasters and finding ways and possibilities for effective protection, safety and community resilience in such situations (Nikolić, Anđelković, 2018).

\section{DISASTER RISK MANAGEMENT}

Managing the risk of natural disasters implies the sum of all activities, measures and programs undertaken before, during and after a disaster in order to avoid a disaster, reduce its impact and recover from the damage suffered (Nikolić et al., 2007). Therefore, the process of managing the risk of natural disasters is a way to reduce risks, limit the consequences and increase society's re- silience to disasters. The goal is to solve the problem of disasters before they occur and threaten development. Essentially, the concept of disaster risk reduction points to the need to reduce exposure to hazards and vulnerability of people and communities, and to improve preparedness and early warning systems of potential risks (Nikolić, Anđelković, 2018).

The effectiveness of risk-reduction strategies is significantly determined by human behavior, which is strictly related to risk perception. Risk perception is influenced by a number of personal variables such as education, gender, etc. (Flynn et al. 1994, Kone and Mullet, 1994, Dosman et al. 2001).

Risk is "a combination of likelihood that a disaster will occur in a certain period of time and with certain negative consequences", while disaster risk reduction is "a policy that is established and pursued in order to prevent new and reduce existing risks through the implementation of integrated and inclusive economic, social, educational, normative, health, cultural, technological, political and institutional measures that enhance the resilience and readiness of the community to respond and mitigate the resulting consequences of the disasters, which leads to strengthening the resilience of the community" (Zakon o smanjenju rizika od katastrofa i upravljanju vanrednim situacijama "Službeni glasnik RS" br. 87/2018). Risk management is a set of measures and activities that are carried out in order to implement disaster risk reduction policy as well as administrative operational and organizational skills and capacities for their implementation (Ibid.).

Disaster risk management consists of three key phases (Nikolić, Anđelković, 2018; Nikolić, Živković, 2010):

- a phase prior to a natural disaster (prevention) - activities undertaken at this stage are aimed at reducing potential human and material losses in the event of a disaster. At this stage an early warning campaign is conducted, plans are prepared within the framework of risk management at the household and community level, etc. The activities undertaken at this stage are called preparedness and mitigation measures; 
- a phase throughout a duration of a natural disaster (intervention) - implies the assurance of direct evacuation, saving lives and taking measures for the protection of the most vulnerable. The activities undertaken at this stage are called measures of immediate response to a disaster;

- a phase after a natural disaster (rehabilitation) - includes undertaking of recovery measures and elimination of consequences of a natural disaster. These activities are called fast response and recovery measures.

All phases of the process of managing the risk of natural disasters are in mutual circular relationships, each phase relies on the other. These phases have no beginning or end. Activities in one phase can overlap with activities in previous phases. Preparedness quickly turns into a response, the response merges with recovery at different moments depending on the extent and type of damage. Similarly, recovery should help initiate the prevention phase, i.e. the motivation of efforts to prevent or reduce the future catastrophic potential.

The functional structure of the management system in preventing natural disasters and acting upon the occurrence of a natural disaster must include a range of problems related to such situations, including the necessary steps to forecast, prevent and eliminate their consequences

Reducing the risk of disasters requires a strong institutional base which can be achieved through capacity strengthening, promotion of appropriate program policies and legislation, effective coordination mechanisms and good management. The management should be supported by appropriate indicators whose values will point to the manner of prevention and/or response to various threats (Savić et al. 2016). In particular, emphasis should be placed on education for disaster risk reduction, especially at community levels, as well as on learning from past natural disasters in order to prevent or mitigate future natural disasters.

\section{COMMUNITY RESILIENCE}

The word "resilience" is of Latin origin and means "to jump back", which implies returning to a former state and the implications of a system to deal with the complexity in conditions of psychological, social, organizational and physical functioning after a disaster (Paton, 2006). Holling (1973) first used the term resilience to describe "a measure of persevering of systems and their ability to absorb changes and disturbances and keep maintaining the same relationships between population or state variables."

Maintaining continuous functioning while anticipating and preventing potential problems regarding improvisation and recombination of resources in new ways may represent the broadest view of resilience (Kendra, Wachtendorf, 2003). Bruneau and Reinhorn (2006) proposed four characteristics of resilience: robustness, redundancy, resourcefulness, and speed.

Robustness in the context of resilience refers to the ability of systems to cope with constraints that impose stress or demand without losing their function. Redundancy can be the extent to which systems show the ability to fulfill their functional requirements during interruptions. Resourcefulness deals with the capacity to find problems, prioritization, and mobilization of resources during interruptions, as well as the utilization of material and human resources in the recovery process. Speed is the ability of systems to reach priorities and goals on time during interruptions. Overall, resilience is the ability of both social and organizational systems (individually and collectively) to effectively absorb, react to, and recover from both internally or externally imposed set of extraordinary demands (Aguirre, 2006). The importance of learning for the development of community resilience comes from evidence that education can contribute to facilitating the availability and implementation of robustness, redundancy, resourcefulness, and rapid resilience components (Irons, Paton, 2017).

One of the top priorities for disaster relief is to save lives. It is vital to build the resilience of people, i.e. to increase the ability of community members to respond and adapt to the consequences of danger. This can help the competent services to provide appropriate disaster relief. The key to developing this capability of a community is developing a social network (support) that works in such a way to help people conceptualize their 
risk, develop ways to effectively reduce this risk and develop ways to carry out these plans in cooperation if the need arises (Paton, 2017). Many international documents point to the need for a proactive approach to learning and education by informing, engaging, motivating people in their local communities to deal with disasters in order to build community resilience (United Nations, 2005; Mundel and Schugurenski, 2008).

\section{LEARNING FROM NATURAL DISASTERS}

Learning from natural disasters is generally considered useful. Individuals and governments learn to cope with all the disaster-related problems, and in this way reduce the damage and human losses in future disasters. More and more literature is available today to support learning from natural disasters. Many social scientists believe that natural disasters offer an opportunity for individuals and policy makers to better adapt themseIves to natural hazards (Birkmann et al. 2010). For example, a landslide risk assessment study (Lee, Jones, 2004) and an analysis of learning from a disaster created by a landslide in Hong Kong (Malone, Ho, 1995), summarize the benefits of learning from past catastrophic events. Jasanoff (1994) points out that learning from disasters leads to better adaptation or even prevention.

Some authors oppose a standard narrative of useful learning from disasters, believing that learning from natural disasters does not have to be undeniably positive (e.g. Brisbane flood, etc.) (Bohenski, Leitch, 2014; Colten, Sumpter, 2009; Meyer, 2011). There are two main reasons why learning from past disasters can have harmful consequences. Firstly, investing in infrastructure protection measures can stimulate settling in areas that are prone to dangers and encourage a false sense of security, which can prevent an individual from going to a safe place when danger occurs. Secondly, if disasters that have occurred in the past were not with tremendous consequences, then the affected individuals do not grasp the future events seriously enough (Plümpera et al. 2017).

It is true that some of the dangers are completely unpredictable or so extreme that no human action can prevent them from turning into disasters. For the most part, dangers turn into disasters only when people have made insufficient efforts in prevention, mitigation, preparedness and adjustment. People are not only victims, but their decisions directly affect the social and economic consequences of natural disasters. Therefore, learning from past disasters, understanding their causes and consequences in order to prevent or mitigate future disasters is the main impact people can make to reduce mortality from disasters (lbid.).

According to Collenteur et al. (2015) learning from disasters is a two-edged sword. Such learning, on the one hand, increases public investment in infrastructure protection measures and in this way mitigates the negative effects of disasters and leads to appropriate reactions of the affected population at the individual level. On the other hand, public and private investments in such early warning systems encourage settlement in highrisk areas (e.g. areas prone to floods, earthquakes, etc.) (Collenteur et al. 2015). For example, Tohoku Tsunami in Japan clearly shows the two-edged sword of learning from past disasters (Plümpera et al. 2017). Exceptional building structures that are regularly reinforced, rigorous earthquake exercises regularly conducted in schools, and public and private institutions, a sophisticated early warning system that relies on sensors that record all seismic activities on islands and shores, as well as an excellent system of shelters resistant to earthquakes and tsunamis, etc. (Chock et al. 2013), are the result of a positive learning from past disasters in Japan. On the other hand, people living on the eastern coast of Japan which was affected by the Tohoku Tsunami did not experience the earthquakes and tsunamis of Tohoku magnitude. All the tsunamis they had in their lifetime were much smaller. Therefore, local authorities and threatened citizens relied too much on infrastructure protection (walls and shelters), which resulted in the large number of affected population staying close to the coast and watching incoming tsunami rather than escaping to the interior or to higher areas (Plümpera et al. 2017).

However, much empirical research supports the beneficial effects of learning from natural disasters. These learning effects are especially higher in places where disasters often occur. Thus, in earthquake-prone areas, earthquake mortality in a global sample decreases (Keefer et al. 2011). Co- 
untries that are often affected by tropical storms have less human and economic losses (Hsiang, Narita, 2012). In fact, individuals and, more importantly, governments learn from past disasters to invest in disaster prevention, preparedness, mitigation and adaptation. On the other hand, the benefits of learning from past disasters seem to be very small in places where disasters rarely occur (Schad et al. 2012).

\section{CONCLUSION}

All natural disasters have their own characteristic causes of origin, a unique scenario, impact on people and the environment, proportions and severity of consequences. They have a large and extremely negative impact on society, economy, community development, they disturb ordinary ways of life, and more frequently, political conditions of life. They slow down the development of the community and require undertaking of special measures by all the subjects in response in emergency situations. However, their consequences can be greatly mitigated by taking appropriate preventive measures, managing disaster risk, learning from disasters, and raising community resilience to respond to natural disasters.

Community resilience must be viewed in direct relation to the ability of community members to cope, adapt, recover and learn from a disaster. The complex nature of a disaster indicates that community resilience is difficult to achieve without professional assistance in the education of community members. In this respect, it is necessary to develop non-formal educational programs that use local "experts" in the community to teach and educate the local population. Community members working together with the support of informal educators can acquire knowledge and skills related to disaster preparedness and response through local social activities and access to information and support from well-connected social networks. This increases the likelihood that disaster education is relevant to local populations and local conditions.
Food and water storage, household evacuation plan, household safety and security, early signal identification, first aid skills, occupational health and safety are key contents to raising community readiness and response capacity. This knowledge should not only relate to any specific disaster but also the benefit of everyday life and the safety of community members. In this context, the readiness of informal educators and the development of a strategy for integrating existing expertise and knowledge on disaster risk reduction into various social activities and contents are of particular importance.

The impact of learning about community resilience can be reflected on building local capacities in assessing the local situation, gathering information during disasters (e.g. community members can gather and report information related to the number of injuries and casualties, the number of people in need, the types of assistance needed, etc.). Community learning and preparedness also provide significant assistance to competent services and authorities to assist effectively, and for the community itself to act without fear and panic. In the aftermath of a disaster, social groups within the community can provide further health and mental support in recovering the community and adapting to changes that have occurred as a result of natural disasters.

Promotion of learning and non-formal education in the concept of disaster risk management aims to jointly build community resilience, which is especially important in disaster-prone areas. Non-formal disaster learning educates and prepares individuals how to cope with disasters, but also connects individuals - members of the community - to be able to cope with changes, adapt and return to their earlier lives.

\section{Acknowledgments}

This work is supported by Serbian Ministry of Education and Science (Project III44006, III42006, III43014). 


\section{REFERENCES}

Anbarci, N., Escaleras, M., Register, C.A.: Earthquake fatalities: the interaction of nature and political economy, J. Public Econ. 89, 2005, 1907-1933.

Aguirre, B.E.: On the concept of resilience, Preliminary Paper No. 356, 2006., Disaster Research Center, University of Delaware, Delaware, available at: http://dspace.udel.edu/handle/19716/2517.

Bruneau, M. and Reinhorn, A.: Overview of the resilience concept, Proceedings of the 8th US National Conference on Earthquake Engineering in San Francisco, California, Earthquake Engineering Research Institute, Vol. 2040, Oakland, CA, 18-22., 2006.

Bohensky, E.L., Leitch, A.M.: Framing the flood: a media analysis of themes ofresilience in the 2011 Brisbane flood, Reg. Environ. Change, 14, 2014, 475-488.

Birkmann, J., Buckle, P., Jaeger, J., Pelling, M., Setiadi, N., Garschagen, M., Fernando, N., Kropp, J.: Extreme events and disasters: a window of opportunity for change? Analysis of organizational, institutional and political changes, formal and informal responses after mega-disasters, Nat. Hazards, 55, 2010, 637-655.

Collenteur, R.A., de Moel, H., Jongman, B., Di Baldassarre, G.: The failed-levee effect: do societies learn from flood disasters? Nat. Hazards, 76, 2015, 373-388.

Colten, C.E., Sumpter, A.R.: Social memory and resilience in New Orleans, Nat. Hazards, 48, 2009, 355-364.

Chock, G., Robertson, I., Kriebel, D., Francis, M., Nistor, I.: Tohuku, Japan, earthquake and tsunami of 2011, Performance of Structures Under Tsunami Load, American Society of Civil Engineers, Structural Engineering Institute, Reston VA, 2013.

Dosman, D., Adamowicz, A., Hrudey, S.: Socioeconomic determinants of health- and food safety-related risk perceptions, Risk Anal. 21, 2001, 2, 307-317.
EM-DAT, 2013. The OFDA/CRED International Disaster Database. Université Catholique de Louvain, Brussels.

Edward, B.: Natural Hazards, second edition. University Press, Cambridge, 2005.

Farooq, U., Ganoe, C.H., Xiao, L., Merkel, C.B., Rosson, M.B. and Carroll, J.M.: Supporting community-based learning: case study of a geographical community organization designing itswebsite, Behaviour \& Information Technology, 26, 2007, 1, 5-21.

Flynn, J., Slovic, P., Mertz, C.: Gender, race, and perception of environmental health risks, Risk Anal. 14, 1994, 6, 1101-1108.

Galjak, M., Nikolić, V.: Ekološka bezbednost i prirodne katastrofe. U: Zbornik radova Savremeni bezbjednosni rizici i prijetnje $i$ njihov uticaj na bezbjednost država regiona, Fakultet bezbjednosti i zaštite, Banjaluka, Republika Srpska, 208221, 2016.

Hsiang, S.M., Narita, D.: Adaptation to cyclone risk: evidence from the global cross-section, Clim. Change Econ. 3, 2012, 2, 1250011.

Holling, C.S.: Resilience and stability of ecological systems", Annual Review of Ecology and Systematics, 4, 1973., 1-23.

Irons, M., Paton, D.: Social media and emergent groups: the impact of high functionality on community resilience, in Paton, D. and Johnston, D.M. (Eds), Disaster Resilience: An Integrated Approach, 2nd ed., Charles C. Thomas, Springfield, IL, pp. 194-211, 2017.

Jasanoff, S.: Learning From Disaster: Risk Management After Bhopal, University of Pennsylvania Press, Philadelphia, edited (with introduction), 1994.

Kahn, M.E.: The death toll from natural disasters: the role of income, geography, and institutions, Rev. Econ. Stat. 87, 2005, 271-284.

Kone, D., Mullet, E.: Societal risk perception and media coverage, Risk Anal. 14, 1994, 1, 21-24.

Kendra, J.M., Wachtendorf, T.: Elements of resilience after the world trade center disaster: re- 
constituting the New York City's emergency operations center, Disasters, 27, 2003, 1, 37-53.

Keefer, P., Neumayer, E., Plümper, T.: Earthquake propensity and the politics of mortality prevention, World Dev. 39, 2011, 9, 1530-1541.

Lee, E.M., Jones, D.K.C.: Landslide Risk Assessment, Thomas Telford Publishing, London, 2004.

Mlađan, D., Cvetković, V.: Classification of Emergency Situations, In: Thematic Proceedings of International Scientific Conference "Archibald Reiss Days", Belgrade, Academy of Criminalistic and Police Studies, 275-291, 2013.

Malone, A., Ho, K.: Learning from landslip disasters in Hong Kong, Built Environ. 21, 1995, 126-144.

Meyer, R.J.: Why we under-prepare for hazards. In: Ronald, J.D., Kettl, D.F., Kunreuther, H. (Eds.), On Risk and Disaster. Lessons from Hurricane Katrina. University of Pennsylvania Press, Philadelphia, 153-174, 2011.

Mündel, K., Schugurensky, D.: Community based learning and civic engagement: Informal earning among adult volunteers in community organizations, New Directions for Adult and Continuing Education, 2008, 118, 49-60.

Nikolić, V., Anđelković, B.: Sistem bezbednosti $i$ zaštite \& razvoj ljudskih resursa $i$ upravljanje znanjem, Fakultet zaštite na radu u Nišu, Niš, 2018.

Nikolić, V., Savić, S., Stanković, M.: Designing a multimedia platform for emergency management, Management of Environmental Quality, 18, 2007., 2, United Kingdom, 198-210.

Nikolić, V., Živković, N.: Bezbednost radne $i$ životne sredine, vanredne situacije i obrazovanje, Fakultet zaštite na radu u Nišu, Niš, 2010.

Oliver-Smith, A., Cutter, S.L., Warner, K., Corendea, C., Yuzva, K.: Addressing Loss and Damage in the Context of Social Vulnerability and Resilience. UNU-EHS Policy Brief 7. United Nations University-Institute for Environment and Human Security, Bonn, 2012.
Paul, B.K.: Environmental Hazards and Disasters: Contexts Perspectives and Management, John Wiley \& Sons, Chichester, 2011.

Palmer S.R., Rees H., Coleman G.: Major chemical incidents: bridging the occupational- public health gap. Occup Med; 50, 2000., 4, 221-5, Available from: http://occmed.oxfordjournals.org/ content/50/4/221.full.pdf+html, accessed, 10. 10. 2001.

Plümpera, T., Quiroz-Floresb, A., Neumayer, E.: The double-edged sword of learning from disasters: Mortality in the Tohoku tsunami, Global Environmental Change, 44, 2017, 49-56.

Petal, M.: Disaster risk reduction education: material development, organization, evaluatio, Regional Development Dialogue Journal, 28, 2008, 2, 1-22.

Paton, D. and Irons, M.: Communication, sense of community, and disaster recovery: a Facebook case study, Frontiers in Communication, 1, 2016, 4.

Paton, D.: Disaster resilience: building capacity to co-exist with natural hazards and their consequences, in Paton, D. and Johnston, D. (Eds), Disaster Resilience: An Integrated Approach, Charles-Thomas Publisher Ltd., Springfield, IL, 3-10, 2006.

Paton, D., Kerstholt, J. and Skinner, I.: Hazard readiness and resilience, in Paton, D. and Johnston, D. (Eds), Disaster Resilience, 2nd ed., Charles C. Thomas, Springfield, IL, 114-135, 2017.

Steinberg, T.: Acts of God Is a Distraction From Human Responsibility The New York Times, 18 November 2013, Available from: http://www. nytimes.com/roomfordebate/, accessed, 20. 07. 2017.

Schumacher, I., Strobl, E.: Economic development and losses due to natural disasters: the role of hazard exposure, Ecol. Econ. 72, 2011, 97-105.

Schwab, A.K., Eschelbach, K., Brower, D.J.: Hazard Mitigation and Preparedness. Wiley \& Sons, Hoboken, 2007. 
Shaluf, I.: An Overview on Disasters, Disaster Prevention and Management, 5, 2007, 687-703.

Savić, S., Stanković,. M., Janačković, G.: Upravljanje rizikom u vanrednim situacijama zasnovano na indikatorima, U: Zbornik radova 11 Međunarodna konferencija Održivi razvoj i zaštita, M\&S 2016, ESSE, 159-172, 2016.

Schad, I., Schmitter, P., Saint-Macary, C., Neef, A., Lamers, M., Nguyen, L., Hilger, T., Hoffmann, $\mathrm{V}$.: Why do people not learn from flood disasters? Evidence from Vietnam's northwestern mountains, Nat. Hazards, 62, 2012, 221-241.

Tobin, A., Montz, E.: Natural Hazards and Technology: Vulnerability, Risk, and Community Response in Hazardous Environments. U: Brunn, S. D., Cutter, S. L., Harrington, J. W. (ur.) Geography and Technology, Dordrecht: Kluwer, 547570, 2007.
United Nations: Hyogo framework for action 2005-2015: building the resilience of nations and communities to disasters, Extract from the Final Report of the World Conference on Disaster Reduction in Kobe, Hyogo, pp. 18-22, 2005.

WHO: Manual for the public health management of chemical incidents, Available from: http:// www.who. int/environmental_health_emergencies/publications/FINAL-PHM-Chemical-Incidents_ web.pdf, 2009, accessed, 11. 03. 2010.

World Nuclear Association.: Fukushima accident 2011. Available from http://worldnuclear. org/info/Safety-and-Security/Safety-of-Plants/Fukushima-Accident 2011/, 2012, accessed, 22. 12. 2013.

Zakon o smanjenju rizika od katastrofa $i$ upravljanju vanrednim situacijama, Službeni glasnik RS, br. 87/2018. 


\section{UPRAVLJANJE RIZICIMA OD KATASTROFE I} OTPORNOST ZAJEDNICE

SAŽETAK: Prirodne katastrofe događaju se svuda u svijetu. One predstavljaju mnoge izazove društvu i pojedincima. Ti izazovi zahtijevaju da ljudi i zajednice budu pripravni i sposobni za učinkovit odgovor koji će ubrzati ponovnu uspostavu društvenog poretka i funkcioniranje društva. Učinkovit odgovor neke zajednice uključuje definiranje strategija za smanjenje rizika od prirodnih katastrofa, a one se sastoje od više elemenata: održavanje izgrađenog okoliša, razvoj sustava upozoravanja, razvoj znanja i sposobnosti za zajednički odgovor itd. Kako procesi upozoravanja i umanjivanja šteta nikad nisu potpuno učinkoviti, razvoj otpornog društva mora se usredotočiti na učenje i razvijanje znanja o zajednici, razumijevanje opasnosti i razvoj sposobnosti za odgovor i prilagodbu.

Ključne riječi: katastrofa, upravljanje rizicima, zajednica, otpornost, učenje 